\title{
Do the Elements of Emotional Intelligence Determine Charismatic Leadership? An Empirical Investigation
}

\author{
Mohona Biswas ${ }^{1^{*}}$ Md. Sahidur Rahman ${ }^{2}$ \\ ${ }^{1}$ Assistant Professor, Department of Management, Rangamati Science and Technology University, Chattogram, Bangladesh \\ ${ }^{2}$ Professor, Department of Management, University of Chittagong, Chattogram, Bangladesh \\ *Corresponding author: biswas.mohona2@gmail.com
}

DOI:https://doi.org/10.38157/business-perspective-review.v3i1.256

Citation: Biswas, M. \& Rahman, M. S., (2021). Do the Elements of Emotional Intelligence Determine Charismatic Leadership? An Empirical Investigation. Business Perspective Review 3(1), 24-40. DOI: https://doi.org/10.38157/business-perspective-review.v3i1.256

\section{Research Article}

\section{Abstract}

Purpose: Emotional intelligence is a critical stimulus of charismatic leadership. This research is an effort to detect the relationships between the elements of emotional intelligence and charismatic leadership.

Method: Purposive sampling technique was adopted to assemble data from 356 bankers working in different private commercial banks in Bangladesh. The Emotional Quotient Index (EQ Index: Rahim et al., 2002) and a Multifactor Leadership Questionnaire (MLQ 5X: Bass EAvolio, 2000) were used to assess emotional intelligence and charismatic leadership respectively. A total of 356 usable responses were received which were analyzed using descriptive statistics, Pearson correlation, and linear regression.

Results: The study revealed that all elements of emotional intelligence, namely, self-awareness ( $r=.64$, $p<.001)$, self-regulation ( $r=.62, p<.001)$, motivation ( $r=.65, p<.001)$, empathy $(r=.63, p<.001)$, and social skills $(r=.59, p<.001)$ were positively correlated with charismatic leadership. It also demonstrated that potential covariates (e.g. experience, age, employee, department, education, gender, and position) shared a negligible correlation with emotional intelligence and charismatic leadership.

Implications: These unique findings would be helpful to academics, scholars, policymakers, and managers/executives of commercial banks to flourish their charisma by cultivating and boosting emotional intelligence to realize a higher level of organizational outcomes.

Limitations: The generalizability of the findings is limited by its particular sampling technique which is less reliable.

Keywords: Emotional intelligence, charismatic leadership, private commercial banks

\section{Introduction}

Private commercial banks (PCBs) are the key players in the financial system of Bangladesh. They foster economic development and respond innovatively to national and global economic 
changes. Nowadays, coronavirus disease (Covid-19) has affected most of the countries' business enterprises. Hence, there are clear indications that the PCBs of Bangladesh might have a higher chance of being affected by the global coronavirus pandemic unless timely remedial measures are taken where the top management has a critical role to play. To accelerate economic recovery in the post-covid-19 situation, PCBs are required to not only recreate themselves for gaining sustainable competitive advantage, but also to highlight the need for human relations, better performance, flexibility, and responsiveness to uncertainty, and change. Therefore, PCBs need to guarantee that they have a skilled workforce to deal with this emergency. A charismatic leader will always impress employees to exhibit improved performance for attaining competitive advantage because $\mathrm{s} /$ he knows how to oversee others' emotions to move through this transition. A plethora of studies has claimed that emotional intelligence (EI) is the main driving force of charismatic leadership (CL). Thus, PCBs mandate the need for emotionally intelligent leaders having charismatic skills in managerial positions customized with the critical business environment of Bangladesh.

EI is a popular concept rising in the field of psychology, and it is one of the latest species of intelligence in the area of organizational behavior (Rahman, Uddin, \& Rahman, 2016; Biswas, Rahman, \& Ferdausy, 2017; Biswas \& Rahman, 2017; Lubbadeh, 2020). According to Northouse (2019) EI deals with our capability to perceive and acknowledge emotions and execute this knowledge to life's errands. It is revealed that EI promotes professional development and much stronger compared with IQ (Rahman et al., 2016; Rahman, 2018).

Furthermore, CL is momentous for influencing personnel for accomplishing organizational targets (Aziz \& Al-Hamdi, 2019). CL has been characterized concerning the existence of emotionally strong themes that guide others based on belief and esteem (Schein, 1989; Carmichael \& Sytch, 2005). Charismatic leaders encourage employees to realize corporate targets (Weinberger, 2003; Aziz \& Al-Hamdi, 2019). However, leaders' charisma and EI may not be responsible for generating a competitive edge only, both may coordinate that process by deploying existing manpower most effectively (Carmichael \& Sytch, 2005).

It is observed that leaders with greater EI will inspire subordinates to demonstrate CL (Brown \& Moshavi, 2005). EI and its elements, viz., self-awareness (SA), self-regulation (SR), motivation (MO), empathy (EM), and social skills (SS) are considered to be the core foundation of CL (Harms \& Crede, 2010; Tareq, Khazaei, \& Khazaei, 2017; Aziz \& Al-Hamdi, 2019).

Globally, numerous investigations have been conducted on EI (as a holistic construct or as a constituent of its elements), and its impact on leadership style (especially transformational and transactional leadership), and job-related behavior. However, there are only a few empirical explorations around the world that confirm the relationship between EI and CL. As far as our knowledge goes, no previous studies have shown how the five elements of EI (i.e., SA, SR, MO, EM, and SS) predict the difference in CL in the context of Bangladesh. This vacuum in research has prompted us to conduct this study. 


\section{Research Objectives}

The purpose of this research is to determine the link between the dimensions of EI and CL in the context of PCBs of Bangladesh. To realize this objective, the present study proposes the following five specific research goals:

i. To explore the link between self-awareness and charismatic leadership perceived by the executives of the PCBs of Bangladesh

ii. To recognize the association between self-regulation and charismatic leadership perceived by the executives of the PCBs of Bangladesh.

iii. To investigate the connection between motivation and charismatic leadership perceived by the executives of the PCBs of Bangladesh.

iv. To assess the relationship between empathy and charismatic leadership perceived by the executives of the PCBs of Bangladesh.

v. To evaluate the relationship between social skills and charismatic leadership perceived by the executives of the PCBs of Bangladesh.

\section{Literature Review}

\subsection{Emotional Intelligence (EI)}

EI is a subject of expanding interest for scholars and researchers (Biswas \& Rahman, 2017; Elom, Okorie, Nduka, Ekuma, \& Otunta, 2018; Giao, Vuong, Huan, Tushar, \& Quan, 2020; Rahman, Ferdausy, Al-Amin, \& Akter, 2020). In 1990, Salovey and Mayer (1990) first proposed the theme 'EI' within the management literature. Mayer, Salovey, and Caruso (2000) described EI as detecting and conveying emotions, incorporating emotions into thoughts, understanding and thoughtful emotions, and therefore the ability to control the emotions of oneself and others. Goleman (1995) an American psychologist wrote the most popular book about EI. Goleman (1995) acknowledged that the cognitive intelligence quotient (IQ) only accounts for 20 percent of the reasons that influence and direct life progress, whereas, the opposite 80 percent is related to additional personal reasons comprising EI (Lubbadeh, 2020).

\subsubsection{Components of EI}

The current research adopted Goleman's mixed paradigm which incorporates the subsequent main ingredients of EI (Rahim et al., 2002, Rahman, Ferdausy, \& Uddin, 2012; Bhattacharjee \& Rahman, 2016; Rahman et al., 2016):

a. Self-awareness: The first component, self-awareness deals with the question 'what is happening inside us?' SA also incorporates a person's knowledge of how a person's feelings about oneself impact others (Rahim et al., 2002; Rahman et al., 2012; Rahman et al., 2016).

b. Self-regulation: The second component, self-regulation speaks about the mastery of skills to supervise one's affection and impetus, to stay calm in unrest conditions, and to maintain calm regardless of emotions (Rahim et al., 2002; Rahman et al., 2012; Rahman et al., 2016).

c. Motivation: Motivation, the third component deals with one's enthusiasm, desire, expectations, and personal confidence (Goleman, 1995, 1998a, 1998b). 
d. Empathy: The fourth component, empathy is associated with understanding others, handling relationships, developing, and supporting others.

e. Social skills: The final component, social skills are essential for understanding human relations, managing disputes, persuading public awareness, and demonstrating collaborative performance (Goleman, 1995, 1998a, 1998b).

\subsection{Charismatic leadership (CL)}

After the resurrection of the scientific area of leadership in the late 1980s and early 1990s, CL aroused tremendous attention from researchers (Conger \& Hunt, 1999; Elbers, 2007). The Greek term charisma denotes 'gift from God' and clarifies the personal characteristics that are usually indescribable in common parlance (Levine, Muenchen, \& Brooks, 2010). House and Baetz (1979) stated that charismatic leaders rely on their talents to have an intense impact on their subordinates. They are capable of converting conventional companies into progressive companies (Beyer, 1999; Aziz \& Al-Hamdi, 2019). The leading researchers of transformational leadership (TFL) claimed that charisma or idealized influence is an essential part of TFL (Bass, 1985; Bass \& Avolio, 1994; Burns, 1978; Rahman et al., 2012). A study was done by Lowe, Kroeck, and Sivasubramaniam (1996) revealed that charisma was consistently the strongest variable among MLQ 5X scales in every size of organization studied.

Northouse (2019) reported that the charisma or idealized influence lies in two aspects:

a. Idealized influence (attributes): Idealized influence (attributes) includes the capability to develop faith in a team by stimulating self-esteem and honor among subordinates (Gill, 2010, p. 53).

b. Idealized influence (behaviors): Idealized influence (behaviors) includes strong ethical and moral behaviors, as well as valuable behaviors like dominance, recognition, selfregulation, and enthusiasm, and self-confidence (D\&D consultants group, 2007, p. 5).

\section{Development of Research Hypotheses}

\subsection{Relationship between SA and CL}

SA is that the foundation for remainder elements of EI (Goleman, Boyatzis, \& McKee, 2002) which is said to inner strength, emotional consciousness, accurate self-estimation, and selfunderstanding. Rahman et al. (2012) investigated the connections between EI and TFL components and found that idealized influence or charisma is associated with emotional awareness, self-confidence, self-discipline, etc. Similarly, a study on the link between TFL and EI by Sosik and Megerian (1999) showed that there is a significant correlation between EI and $\mathrm{CL}$, and therefore the leader's SA alleviates this relationship. Hence, emotionally smart leaders demonstrate greater charisma. Tareq et al. (2017) also examined the affiliation among EI components and CL. They found around 70\% of variances in CL are explained by EI and its components (SA, SR, EM, and SS). Besides, Wang, Chou, and Jiang (2005) reported that a relationship does exist between SA and CL. Therefore, it is assumed that there would be a 
significant and positive correlation between CL and SA. Therefore, the subsequent hypothesis can be established:

H1: There is a positive relationship between $S A$ and $C L$ perceived by the executives of the PCBs of Bangladesh.

\subsection{Relationship between SR and CL}

Leaders with EI can monitor and handle their emotions as well as the emotions of others can exhibit greater CL (Aziz \& Al-Hamdi, 2019). Emotionally balanced employees are good for managing stress as they are self-aware, self-regulated, and adaptable (Wang et al., 2005) which is a characteristic of CL (Aziz \& Al-Hamidi, 2019). Idealized influence or charisma is associated with self-control (Rahman et al., 2012). According to Ashakanasy, Härtel, and Daus (2002) if leaders attain and apply their emotional competencies and charismatic skills, it will motivate them to spice up their performance and make a superior decision. Palmer, Walls, Burgess, and Stough (2001) investigated whether EI shares positive relation to effective leadership. They reported that the power to regulate the inner emotions of themselves and others is positively associated with CL behavior. Similarly, during a study, Tareq et al. (2017) identified that SR significantly predicts CL. Thus, SR skills acted as a supplement or enhancer of CL behaviors (Chung, Chen, Lee, Chen, \& Lin, 2011). Al-Hamdi (2019) also studied the role of EI and its components on CL of the workers of private organizations in Oman. Therefore, it is obvious from the above discussion that SR and CL have a direct correlation. Hence, the researchers have established the following hypothesis:

H2: There is a positive relationship between SR and EI perceived by the executives of the PCBS of Bangladesh.

\subsection{Relationship between MO and CL}

Charismatic leaders are profoundly motivated to depend on values, firm beliefs, and desire for a bright destiny (Shamir, House, \& Arthur, 1993). Ashkanasy et al. (2002) revealed that EI and its elements are almost like CL, as leaders with charismatic leaders must inspire employees emotionally to attain goals and objectives, and emotionally, and be sensitive to the needs of followers. Tareq et al. (2017) also claimed that MO is essential as the leader knows how to attain goals and objectives despite obstacles. If the leader spreads and motivates such positive emotions about goals, such contagion will be a part of CL (Tareq et al., 2017). Thus, EI has incremental validity in predicting charisma, through MO. So, the subsequent assumption can be made:

Hypothesis 3: There is a positive relationship between $M O$ and $C L$ perceived by the executives of the PCBs of Bangladesh.

\subsection{Relationship between EM and CL}

Empathetic leaders are generally marvelous at handling interpersonal relationships, supporting, and establishing connections with other people which is crucial as the leader realizes the way to communicate his principles to others (Tareq et al., 2017). Emotionally balanced employees can 
acknowledge and tune-up to the necessities of their subordinates and that is a nature of CL (Aziz \& Al-Hamidi, 2019; Wang et al., 2005). Managing the emotions of followers comprises empathetic and using relevant gestures, language, and facial expressions (Tareq et al., 2017). If a leader shows such good feelings towards his objectives, then this contagion will become a portion of CL (Tareq et al., 2017). EM prompts making better choices and provides superior and legitimate responses towards activities and occasions (Brackett, Rivers, Shiffman, Lerner, \& Salovey, 2006) which is additionally a characteristic of CL. This argument reveals a link between EM and CL (Aziz \& Al-Hamidi, 2019). Barbuto and Burbach (2006) showed that empathetic leaders see themselves as charismatic leaders (a component of TFL) and are seen intrinsically by their subordinates. Tareq et al. (2017) also identified whether the independent variable (EM) has exaggerated the dependent variable (charisma) and found that EM has a constructive association with CL. The perspective of this study is that empathetic pioneers can actively allure charisma among followers. Thus, the following assumption can be considered:

H4: There is a positive relationship between EM and CL perceived by the executives of the PCBs of Bangladesh.

\subsection{Relationship between SS and CL}

The leaders with smart social expertise can promote their leadership through effective SS which could prompt better charisma in an organization (Aziz \& Al-Hamdi, 2019). It is noteworthy that SS can make an enormous contribution in impacting supporters' impressions of their leaders' charisma and honesty (Groves, 2005; Tareq et al., 2017; Dasborough \& Ashkanasy, 2002). Abbasiyannejad et al. (2015) stressed the sound connection among leaders and therefore the supporters reported that leaders without the SS cannot be considered charismatic leaders. It was additionally discovered that charismatic leaders will pay more attention to team interests rather than personal interests (Shamir et al., 1993). SS is so imperative to regulate emotions because it is viewed as perhaps the best capacity to coexist with social objects (Gross, 1998). Tareq et al. (2017) revealed that a positive connection lies between SS and CL. Besides, Aziz and Al-Hamdi (2019) explored the effect of the elements of EI on CL in the private organizations in Oman and concluded that SS has a significant impact on CL. This strong association between SS and CL creates a logical notion to develop the subsequent proposition:

Hypothesis 5: There is a positive relationship between SS and CL perceived by the executives of the PCBS of Bangladesh.

\section{Research Framework}

The authors developed the subsequent research framework to illustrate the relationship among self-awareness (SA), self-regulation (SR), motivation (MO), empathy (EM), and social skills (SS), and Charismatic Leadership (CL). 


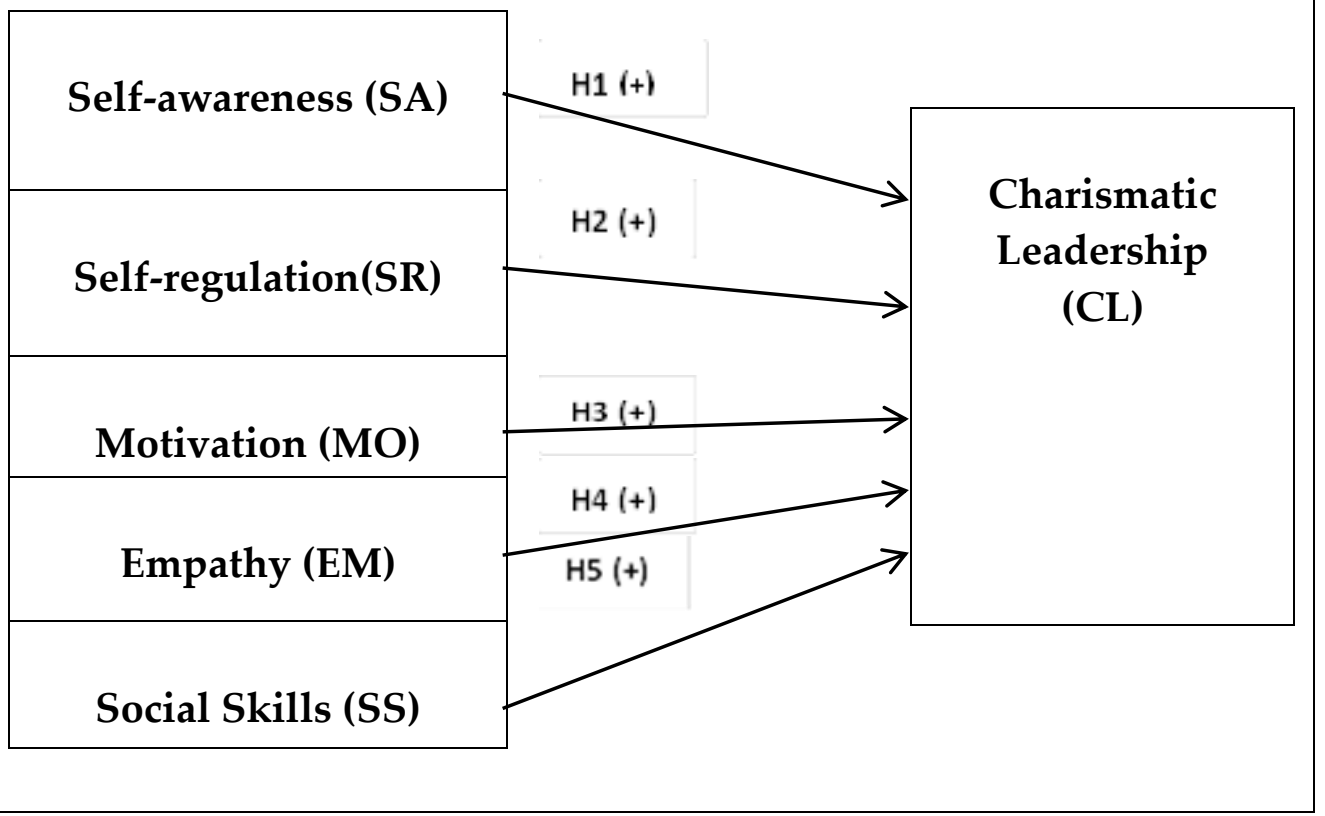

Fig. 1: Research Framework of the study

\section{Banking Sector of Bangladesh}

In Bangladesh, private commercial banks (PCBs) have tremendous contributions in stimulating financial development by securing the interests of depositors and guaranteeing financial strength. Under the complete surveillance of Bangladesh Bank, 42 PCBs are working with numerous branches in Bangladesh (Bangladesh Bank, 2020).

This investigation will provide a precise outline of the dynamic environment of the PCBs in Bangladesh, which will contribute to persuading the managers, decision-makers, executives, and other stakeholders of PCBs in case of identifying emotionally capable candidates having charismatic skills which can, in turn, help to expand workplace satisfaction.

\section{Research Methods}

This is an exploratory investigation in which quantitative techniques were utilized to gather data and test hypotheses to assess the relationship between variables. The authors adopted positivism research philosophy as it manages a large number of samples and quantitative procedures. The elements of EI for example, SA, SR, MO, EM, and SS were used as independent variables and CL was used as the dependent variable.

\subsection{Population and Sample Size}

Approximately 107,000 bankers are working in forty-two scheduled PCBs of Bangladesh that constitute our population (Bangladesh Bank, 2020). Target respondents were bankers working at different PCBs situated in Chattogram city at the upper, middle, and lower levels of management.

Saunders, Lewis, and Thornhill (2012) postulated that if the population size is 100000 or more, with a 95\% confidence level, and a 5\% error margin, the minimum sample size should be 383 . 
Likewise, Zikmund (2009) pointed out that if the population size is 100000 or more, with a $95 \%$ confidence level, and a 5\% error margin, the minimum sample size should be 322 . The current research considers 356 usable responses as the research sample.

\subsection{Survey Instruments}

The investigation embraces the accompanying measures to gather data from the participants:

\subsubsection{EQI}

The Emotional Quotient Index (EQI) of Rahim et al. (2002) was utilized with 40 items for evaluating the elements of EI (namely SA, SR, MO, EM, and SS) proposed by Goleman (1998a). The participants were requested to communicate their perspectives on the EI competencies of their managers. The Likert scale was applied to represent their view. The scoring standard ranges from 1 (strongly disagree) to 7 (strongly agree). The greater the score, the greater the manager's EI.

\section{2. 2 MLQ 5X}

CL was estimated utilizing the Multifactor Leadership Questionnaire (MLQ 5X: Bass \& Avolio, 2000) with 8 items to evaluate executives' perception of managers' CL. The Likert scale was applied to represent their view, which is divided into 4 points (Not at all $=0$, Once in a while $=1$, Sometimes=2, Fairly often $=3$, Frequently $=4$ ).

\section{3 Data Collection Procedure}

The authors adopted the purposive sampling technique to assemble data through survey questionnaires because they had the freedom to gather data from conveniently accessible executives. Furthermore, bankers were invited to participate in this study where the authors obtained consent from the senior management. Cooper and Schindler (2011) recommended this method because it frequently seems to provide acceptable results compared to probability sampling. Moreover, this method might be the only viable option as the complete populace may not be accessible under certain circumstances (Cooper \& Schindler, 2011).

The survey questionnaires were distributed to 500 respondents performing at 20 sample PCBs to address the research questions. The researchers went through five weeks for collecting data from the respondents. In the end, a complete of 356 (71\%) available responses were received. Afterward, the original data loaded into an Excel record, and then entered into the SPSS Statistics 23.0 (data editor) for testing hypotheses.

\subsection{Reliability and Validity}

Reliability is how much an estimating system produces steady results (Islam, 2015). Cronbach's alpha is the broadly utilized technique for evaluating the reliability of the scale (Hair, Anderson, Tatham, \& Black, 2003; Biswas \& Rahman, 2017, Biswas et al., 2017). The value of this technique ranges from 0 to 1 ; however, for the scale to be reliable, a satisfactory value must be greater than 0.60 (Malhotra, 2002; Cronbach, 1951; Rahman et al., 2012). Cronbach's alpha values of SA, SR, 
$\mathrm{MO}, \mathrm{EM}, \mathrm{SS}$, and CL for the current study were $0.82,0.82,0.85,0.82,0.79$ and 0.73 respectively. Therefore, these two tools (EQI and MLQ 5X) were profoundly reliable for gathering data.

Through extensive research in different countries along with Bangladesh, the validity of the instrument is guaranteed (Bass \& Avolio, 2000; Rahim et al., 2002; 2006; Biswas \& Rahman, 2017; Rahman et al., 2020).

\section{Results}

The mean and standard deviation of EI and its elements are demonstrated in Table- 1. Pearson's correlation analysis was carried out to examine the current study.

Table 1: Means (M), Standard Deviations (SD), and Correlations of Variables

\begin{tabular}{|c|c|c|c|c|c|c|c|c|c|}
\hline \multirow[t]{2}{*}{ Variables } & \multirow[t]{2}{*}{$\mathbf{M}$} & \multirow[t]{2}{*}{ SD } & \multirow[t]{2}{*}{$\alpha$} & \multicolumn{6}{|c|}{ Correlations } \\
\hline & & & & 1 & 2 & 3 & 4 & 5 & 6 \\
\hline 1. SA & 6.25 & 0.57 & 0.82 & 1 & & & & & \\
\hline 2. SR & 6.20 & 0.62 & 0.82 & $0.80^{* *}$ & 1 & & & & \\
\hline 3. MO & 6.24 & 0.62 & 0.85 & $0.84^{* *}$ & $0.84^{* *}$ & 1 & & & \\
\hline 4. EM & 6.22 & 0.60 & 0.82 & $0.82^{* *}$ & $0.79^{* *}$ & 0.83 & 1 & & \\
\hline 5. SS & 6.21 & 0.57 & 0.79 & $0.81^{* *}$ & $0.80^{* *}$ & $0.82^{* *}$ & $0.81 * *$ & 1 & \\
\hline 6. CL & 3.46 & 0.39 & 0.73 & $0.64^{* *}$ & $0.62^{* *}$ & $0.65^{* *}$ & $0.63^{* *}$ & $0.59^{* *}$ & 1 \\
\hline
\end{tabular}

(Note: $\mathrm{N}=356$; Correlation is significant at the 0.01 level (2-tailed); $\mathrm{SA}=$ Self-awareness, $\mathrm{SR}=$ Self-regulation, $\mathrm{MO}=\mathrm{Motivation}, \mathrm{EM}=\mathrm{Empathy}$, and SS = Social skills; $\mathrm{CL}=$ Charismatic Leadership)

Source: Field Survey 2020

A review of Table 1, demonstrates that a significant relationship exists among the elements of EI and CL: a. SA (r=.64, p<.001), b. SR ( $r=.62, p<.001)$, c. MO ( $r=.65, p<.001)$, d. EM $(r=.63, p<$ $.001)$, e. SS $(\mathrm{r}=.59, \mathrm{p}<.001)$. The magnitude or strength of the association is strong for SA, SR, $\mathrm{MO}$, and EM and moderate for SS consistent with Evans's (1996) classification. r represents the positive or negative direction of the association. The result demonstrates that the direction of the correlation is positive which implies that these factors will rise together (higher EI is linked with higher $\mathrm{CL}$ ). The $\mathrm{p}$-value demonstrates the connection is significant. The outcomes depend upon $n=356$ cases which resemble the sample size of the present study, so there are not any lost values in data. So, it can be said that the parts of EI (SA, SR, MO, EM, and SS) shared positive and significant relationships with $\mathrm{CL}$ among the target respondents. The outcome of regression analysis concerning the dimensions of EI with CL is shown in Table 2. In Table 2, the result shows that the unstandardized B coefficients are significant and positive numbers for SA, SR, $\mathrm{MO}$, EM, and SS (higher EI is associated with higher CL) which makes perfect intuitive sense. The beta coefficient tells us how strongly the independent variable is associated with the dependent variable. The standardized beta values for SA, SR, MO, EM, and SS are 0.64, 0.62, $0.65,0.63,0.59$ respectively, meaning that if the components of EI increase, CL will increase by $64 \%, 62 \%, 65 \%, 63 \%$, and 59\% respectively. T-test reveals that all values are significant $(\mathrm{p}<0.01)$ 
and in this manner, it can be said that they are unique to zero. Besides, regression analysis shows that there is a positive connection (strong) between SA and CL $(\beta=0.72, t=15.59, p<.01)$.

Table 2: Results of Regression Analysis in respect to the elements of EI with CL

\begin{tabular}{|c|c|c|c|c|c|c|c|}
\hline \multirow{3}{*}{\multicolumn{2}{|c|}{ Variables }} & \multicolumn{2}{|c|}{$\begin{array}{l}\text { Unstandardized } \\
\text { Coefficients }\end{array}$} & \multirow{2}{*}{$\begin{array}{c}\begin{array}{c}\text { Standardized } \\
\text { Coefficients }\end{array} \\
\text { Beta }\end{array}$} & \multirow{2}{*}{$\begin{array}{c}\text { T- } \\
\text { statistic } \\
\text { Value }\end{array}$} & \multirow[t]{2}{*}{$R^{2}$ Value } & \multirow{2}{*}{$\begin{array}{c}\text { F-statistic } \\
\text { Value } \\
\text { (ANOVA) }\end{array}$} \\
\hline & & B & $\begin{array}{c}\text { Standard } \\
\text { Error }\end{array}$ & & & & \\
\hline & SA & 0.72 & 0.05 & 0.64 & $15.59^{* *}$ & 0.41 & $243.12^{* *}$ \\
\hline & SR & 0.65 & 0.04 & 0.62 & $14.92^{* *}$ & 0.39 & $222.77^{* *}$ \\
\hline & MO & 0.67 & 0.04 & 0.65 & $16.01^{* *}$ & 0.42 & $256.18^{* *}$ \\
\hline & EM & 0.67 & 0.04 & 0.63 & $15.22^{* *}$ & 0.39 & $231.74^{* *}$ \\
\hline & SS & 0.67 & 0.05 & 0.59 & $13.67^{* *}$ & 0.34 & $186.84^{* *}$ \\
\hline
\end{tabular}

Correlation is significant at the 0.01 level (2-tailed); SA = Self-awareness, $\mathrm{SR}=$ Self-regulation, $\mathrm{MO}=$ Motivation, $\mathrm{EM}=\mathrm{Empathy}$, and SS = Social skills; CL= Charismatic Leadership) Source: Field Survey, 2020

The result of the $\mathrm{R}^{2}$ is 0.41 regarding $\mathrm{SA}$ and CL, which indicates a strong effect size according to Evans's (1996) effect size determination score. It reveals that $41 \%$ variances in CL are explained by SA. Similarly, regression analysis displays that SR shares a significant and positive link (strong) with $\mathrm{CL}(\beta=0.65, \mathrm{t}=14.92, \mathrm{p}<.01)$. The result of the $\mathrm{R}^{2}$ is 0.39 between $\mathrm{SR}$ and $\mathrm{CL}$, which indicates a strong effect size (Evans, 1996). It indicates that $39 \%$ variances in CL are explained by SR. From regression results, it is clear that a significant positive (strong) relationship exists between $\mathrm{MO}$ and $\mathrm{CL}(\beta=0.67, \mathrm{t}=16.01, \mathrm{p}<.01)$. The result of the $\mathrm{R}^{2}$ is 0.42 between $\mathrm{MO}$ and $\mathrm{CL}$, which indicates a strong effect size (Evans, 1996). Table 2 also demonstrates a significant (strong) relation exists between EM and $C L(\beta=0.67, t=15.22, p<.01)$. It reveals that about $39 \%$ of the variances in CL are explained by EM which indicates a strong effect size (Evans, 1996). A review of the above table demonstrates that regression analysis shows a significant and positive relation (moderate) exists between SS and CL $(\beta=0.67, t=13.67$, $p$ $<.01$ ) and the result of the $\mathrm{R}^{2}$ is 0.34 between SS and CL, which shows a moderate effect size (Evans, 1996). It indicates that 34\% of variances in CL are explained by SS. Moreover, F values in Table 2 reveals that overall, the model applied can significantly predict the dependent variable, CL. So, it has been suggested that EI and its elements could be vital predictors of CL. Review of Table 3 demonstrates that only $4 \%$ and $5 \%$ of the variance in EI and CL were clarified by demographic aspects (e.g. experience, age, employee, department, education, gender, and position), which indicates a weak effects size, according to Evans (1996) effect size 
determination score. Among the predictors only department and position are significant. It demonstrates that a greater piece of variance in EI and CL cannot be clarified.

Table 3: Results of Regression Analysis regarding Demographic attributes with EI and CL

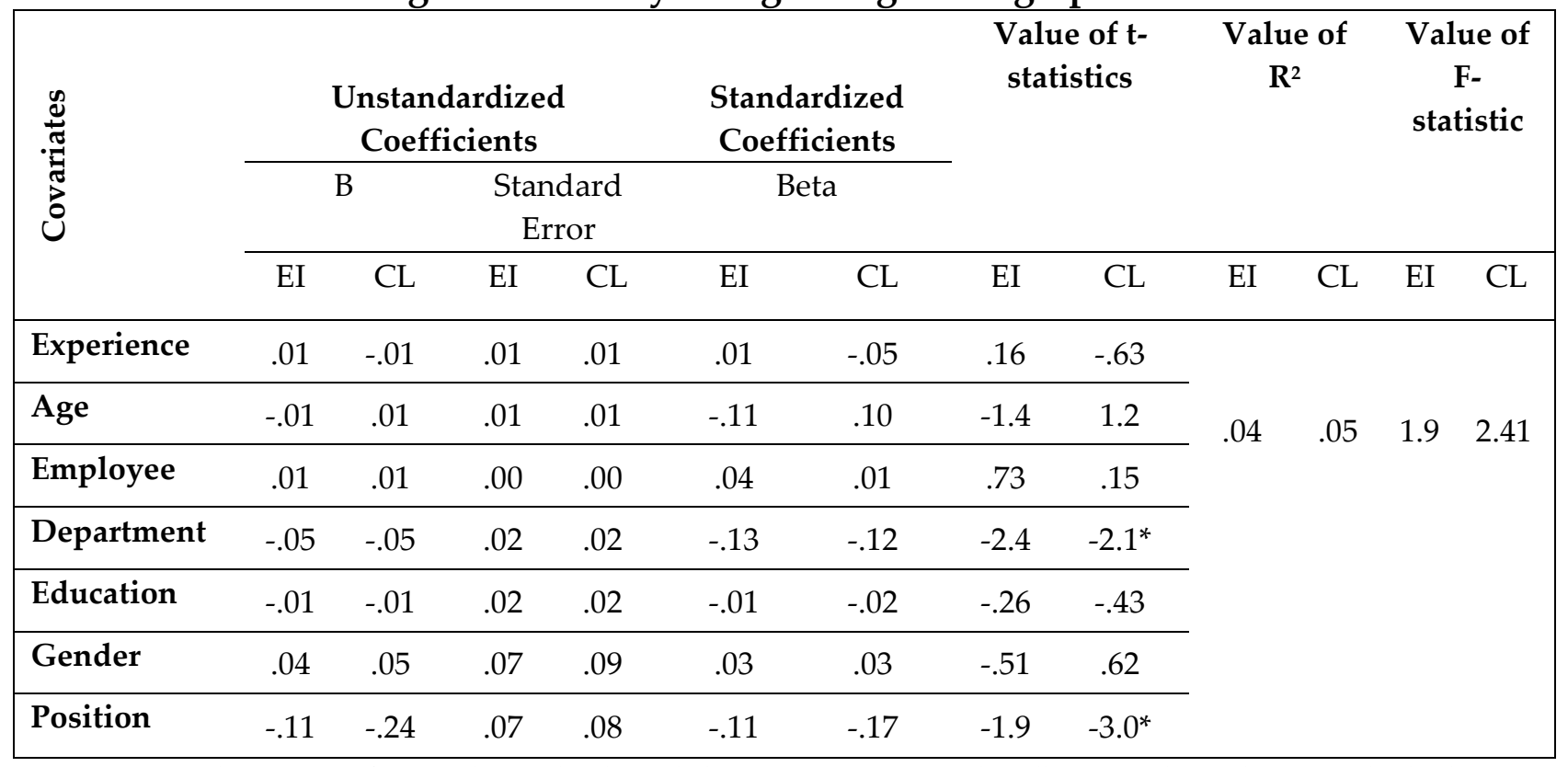

Note: Correlation is significant at the 0.01 level (2-tailed); N=356; EI = Emotional Intelligence and CL=Charismatic leadership Source: Field Survey, 2020

\section{Discussions}

This research investigates the connections among the elements of EI and CL as perceived by respondents. The first hypothesis stated that there is a positive link between SA and CL as perceived by the executives. The results demonstrated that SA and CL were significantly related $(\mathrm{r}=.64, \mathrm{p}<.01)$ and the strength of the association was strong. Hence, the outcomes of this study supported this claim. Additionally, regression analysis revealed that SA shared a strong and positive association with $\mathrm{CL}(\beta=0.72, \mathrm{t}=15.59, \mathrm{p}<.01)$. Regression analysis revealed the independent variable, SA, explained $41 \%$ variances in the dependent variable, CL, which indicates a strong effect size (Evans, 1996). Therefore, the results showed that CL was strongly related to SA skills used by the managers. This positive connection is reliable with the claims of earlier research results (Wang et al., 2005; Rahman et al., 2012; Tareq et al., 2017). Hence, the current study confirmed that the managers at the PCBs of Bangladesh who score high in SA might tend to display a more CL behavior.

The second hypothesis stated that there is a positive connection between SR and CL as perceived by executives. The quantitative results of this study found that SR and CL imparted a significant and positive correlation (strong) $(\mathrm{r}=0.62, \mathrm{p}<.01)$. Hence, the hypothesis was accepted. Similarly, regression analysis revealed that SR and CL were significantly connected ( $\beta$ $=0.65, \mathrm{t}=14.92, \mathrm{p}<.01)$. Regression analysis revealed that $39 \%$ variances in $\mathrm{CL}$ were explained by SR which indicates a strong effect size (Evans, 1996). This positive association is steady with the claims of the prior investigation comes about (Wang et al., 2005; Chung et al., 2011; Rahman et 
al., 2012; Tareq et al., 2017; Aziz \& Al-Hamdi, 2019). Thus, the central themes of the findings are that SR is a critical element in determining the charismatic skills of managers.

The third hypothesis stated that there is a positive liaison between MO and CL as perceived by the respondents. The analyses revealed that $\mathrm{MO}$ shared a significant and positive relation (strong) with CL $(\mathrm{r}=0.65, \mathrm{p}<.01)$. Therefore, this hypothesis was accepted. Likewise, regression analysis revealed a positive connection between $\mathrm{MO}$ and $\mathrm{CL}(\beta=0.67, \mathrm{t}=16.01, \mathrm{p}<.01)$. Regression analysis revealed that $42 \%$ variances in CL were explained by $\mathrm{MO}$ which indicates a strong effect size (Evans, 1996). This positive association was steady with past research results (Ashkanasy et al., 2002; Wang et al., 2005; Rahman et al., 2012; Tareq et al., 2017). Thus, it can be said that $\mathrm{MO}$ may be a vital factor in flourishing charisma among leaders.

The fourth hypothesis stated that a positive relationship exists between EM and CL as perceived by the respondents. The quantitative results of this study found that there was a strong positive link between independent EM and dependent CL $(r=0.63, p<.01)$. Hence, the hypothesis was accepted. Similarly, regression analysis revealed a significant positive relationship between EM and $C L(\beta=0.67, t=15.22, p<.01)$. Regression analysis revealed that $39 \%$ of the variances in $C L$ were explained by EM which indicates a strong effect size (Evans, 1996). A plethora of studies have reported that EM can significantly predict CL behaviors (Barbuto \& Burbach, 2006; Brackett et al., 2006; Rahman et al., 2012; Tareq et al., 2017; Aziz \& Al-Hamidi, 2019). Thus, this study confirmed that the bankers who score high in EM might tend to display more charismatic behavior.

The last hypothesis stated that a positive liaison remains between SS and CL as perceived by the bankers. The results of this research showed that SS was positively correlated (moderate relationship) $(\mathrm{r}=.59, \mathrm{p}<.01)$ with CL. Therefore, this hypothesis was also accepted. Besides, regression analysis showed a SS imparted a moderate and significant relationship with CL $(\beta=0.67, t=13.67, p<.01)$. Regression analysis revealed that only $34 \%$ of variances in $C L$ were explained by SS which indicates a moderate effect size (Evans, 1996). The findings of this research were parallel with the previous research findings which had shown that SS was correlated with CL (Groves, 2005; Abbasiyannejad et al., 2015; Tareq et al., 2017; Aziz \& AlHamdi, 2019). But, the results also revealed that SS values are moderately significant for boosting the charisma of executives. This may be due to the nearby culture where a few managers are noticeably prepared to take care of workers' problem, however, may not be able directly to deal with their employees' emotions to resolve conflicts. This prescribes that the top management of any organization should seek to boost their officials' social skills at administrative levels.

Furthermore, the previous investigations have revealed that EI level varies from person to person, culture to culture, and from clan to clan (Nandwana \& Joshi, 2010; Aziz \& Al-Hamdi, 2019). Correspondingly, the degree of EI differs by socio-demographic features (i.e., experience, age, employee, department, education, gender, and position) (Pooja \& Kumar, 2016; Akyol \& Akdemir, 2019). This study also examined the impact of socio-demographic attributes on EI and CL and showed that only $4 \%$ and $5 \%$ of the variance in EI and CL were explained by socio- 
demographic covariates (e.g. experience, age, employee, department, education, gender, and position).

\section{Implications}

This study has assembled and analyzed data from 20 sample private commercial banks in Bangladesh to generate relevant empirical outcomes. Therefore, the outcomes of this research have both theoretical and applied impact in terms of implications. The vital theoretical implication was of using EQI, MLQ 5X tools to evaluate the behavior of managers. In this research, the conceptual framework was verified from the perspective of the theoretical framework, that is, each element of EI can predict the difference in CL. In methodological implication, common method variance (CMV) was prevented because data regarding independent and dependent variables were collected from non-same sources. The significant managerial implication is that higher administration of any work organization like telecommunications, manufacturing, garments industry, and so forth can utilize these results to persuade officials to cultivate incredible charisma as well as EI competencies so that they might improve their creative potential to figure on challenging tasks. Likewise, relationships among the components of EI and CL are important in the field of organizational behavior, human resource development, and leadership as this study will provide clear guidelines to employees on the best way to master and amplify their EI skills (such as self-awareness, self-regulation, motivation, empathy, and social skills) and CL for advancing the strategic capability of the organizations. This study also demonstrated the impact of socio-demographic attributes on the EI level of the bankers working at the PCBs of Bangladesh. Therefore, this kind of research will satisfy the need for research in the context of Asian culture or non-Western environments because this study is aimed at developing countries like Bangladesh.

\section{Limitations}

There are a few limitations of the current research. First, the use of the purposive sampling technique which may limit the generalizability of the results. Second, the potential common method bias that may result from the use of single-source data and cross-sectional data, which may limit the current research results. Third, the authors had to limit the sample size $(n=356)$

that may not represent the large population. Samples are only extracted from the private commercial banks located in Chattogram city, Bangladesh which may be another restriction. Forth, this study treats the elements of EI as independent variables and CL as a dependent variable and it does not address the intermediate or moderating variables that provide complete knowledge of EI and CL. Fifth, this investigation didn't acknowledge public banks or foreign banks. Hence, the statistical results of this survey cannot be extended to the entire banking sector.

\section{Direction for Further Studies}

Future research can be carried out through which multi-source and multi-wave data can be collected to enhance the intensity of the investigation. A future inquiry should plan to 
incorporate some territories such as the role of emotionally intelligent leaders in increasing productivity or reducing subordinates' absenteeism. Moderating or mediating variables can also be considered to test the relationship. Furthermore, future research should consider a large number of sample sizes (Brown \& Schutte, 2006) to generalize the research results to the whole population. However, the results demonstrate that there are strong correlations among all four components of EI and CL except SS skills. This fact stipulates that proper training and development programs are essential for regulating and enhancing emotional capabilities, which may lead to the development of SS skills and enhance charisma among officials with supervisory obligations (Bagheri, Kosnin, \& Besharat, 2016; Aziz \& Al-Hamdi, 2019) to gain more productive, supportive, and healthy experiences at the workplace.

\section{Conclusion}

The relationships between EI (counting each of the elements of EI) and CL perceived by the executives at the PCBs of Bangladesh were explored in this investigation. Several conclusions can be drawn from the results. First, the level of EI perceived by the bankers was at a high level. Second, the EQI scales had a high level of internal consistency and the MLQ 5X had a satisfactory level of internal consistency for CL. Third, quantitative investigation of the study confirmed that all five components of EI i.e., SA, SR, MO, EM, and SS imparted a significant and positive connection to CL. Fourth, an in-depth analysis of each of the components of EI showed that out of the five elements, SA, SR, MO, EM shared a noteworthy and strong relationship with CL. However, a moderate relationship was found between SS and CL. The findings of the regression analysis were also steady with this result. This result stipulates that the top administration of any organization should try to enhance their officials' social skills at administrative levels. Fifth, the results further showed that demographic covariates imparted a negligible connection to EI and CL.

Author Contributions: Mohona Biswas conceived the idea, collected the data, and wrote the paper; Md. Sahidur Rahman analyzed the data, made the necessary corrections, and revised the whole paper.

Conflict of Interest: The authors declare no conflict of interest.

\section{REFERENCES}

Abbasiyannejad, M., Silong, A. D., Ismail, I. A., Othman, J., Wahiza, N., \& Wahat, N. W. A. (2015). Charismatic Leadership and Society. International Research Journal of Social Science, 4(1), 68-73.

Akyol, M. A., \& Akdemir, E. (2019). Comparison of Emotional Intelligence Levels and Problem Solving Skills of Prospective Teachers According to Different Variables. World Journal of Education, 9(3), 131-141.

Ashakanasy, N. M., Härtel, C.E.J., \& Daus, C.S. (2002). Diversity and emotion: the new frontiers in organizational behavior research. Journal of Management, 28(3), 307-338.

Aziz, M. F., \& Al- Hamdi, S. S. (2019). Does Emotional Intelligence Predict Charisma In The Leaders? International Journal of Economics, Commerce, and Management, VII (7), 244-255. 
Bagheri, Z., Kosnin, A. M., \& Besharat, M. A. (2016). Improving Emotion Regulation skills through an Emotional Intelligence Training Course. Khazar Journal of Humanities \& Social Sciences, 19(4), 306-319.

Barbuto, J., \& Burbach, M. (2006). The Emotional Intelligence of Transformational Leaders: A field Study of Elected Officials. The Journal of Social Psychology, 146(1), 51-64.

Bass, B. M. (1985). Leadership and performance beyond expectations. New York: The Free Press.

Bass, B. M., \& Avolio, B. J. (1994). Transformational leadership and organizational culture. International Journal of Public Administration, 17(3/4), 541-554.

Bass, B., \& Avolio, B. (2000). Multifactor leadership questionnaire: Technical report. Mind Garden, Redwood City, CA.

Beyer, J. M. (1999). Taming and promoting charisma to change organizations. The Leadership Quarterly, 10(2), 307330.

Bhattacharjee, S., \& Rahman, M.S. (2016). Assessing the Relationship among Emotional Intelligence, Creativity and Empowering Leadership: An Empirical Study. Dhaka University Journal of Business Studies, 37(1), 198-215.

Biswas, M., \& Ferdausy, S. (2015). Relationships between Emotional Intelligence and Leadership Styles at the Private Commercial Banks of Bangladesh. The Chittagong University Journal of Business Administration, 30(1), 249-272.

Biswas, M., \& Rahman, M.S. (2017). Role of Emotional Intelligence in Transformational Leadership and Leadership Outcomes. BGC Trust University Journal, 4, 187-206.

Biswas, M., Rahman, M.S., \& Ferdausy, S. (2017). Role of Emotional Intelligence in Solving Problems in the Private Commercial Banks of Bangladesh. The Comilla University Journal of Business Studies, 4(1), 51-66.

Brackett, M. A., Rivers, S. E., Shiffman, S., Lerner, N., \& Salovey, P. (2006). Relating emotional abilities to social functioning: a comparison of self-report and performance measures of emotional intelligence. Journal of personality and social psychology, 91(4), 780-795.

Brown, F.W., \& Moshavi, D. (2005). Transformational leadership and emotional intelligence: a potential pathway for an increased understanding of interpersonal influence. Journal of Organizational Behavior, 26, 867-871.

Brown, R., \& Schutte, N. (2006). Direct and indirect relationships between emotional intelligence and subjective fatigue in university students. Journal of Psychosomatic Research, 60, 585-593.

Burns, J. M. (1978). Leadership. New York: Harper \& Row.

Carmichael, D. B., \& Sytch, M. (2005). Emotional Intelligence, Organizational Legitimacy, and Charismatic Leadership. Academy of Management Journal.

Chung, A., Chen, I.H., Lee, A. Y. P., Chen, H. C., \& Lin, Y. (2011).Charismatic Leadership and Self-leadership. Journal of Organizational Change Management, 24(3), 299-313.

Conger, J.A., \& Hunt, J.G. (1999). Overview charismatic and transformational leadership: taking stock of the present and future (part I). The Leadership Quarterly, 10(2), 121-127.

Cooper, D., \& Schindler, P. (2011). Business research methods. USA: McGraw-Hill.

Cronbach, L. J. (1951). Coefficient alpha and the internal structure of tests. Psychometrika, 16, 297-334.

Dasborough, M. \& Ashkanasy, N. (2002). Emotion and Attribution of Intentionality in Leader-Member Relationships. The Leadership Quarterly, 13(5), 615-634.

D\&D Consultants Group. (2007). $M L Q^{\mathrm{TM}}$ Report. Romania: Mindgarden Inc. Retrieved from $<$ https://files.acrobat.com/a/preview/c76a35ae-0778-45ac-a562-02d774f1ec2c>.

Elbers, N. (2007). Charismatic leadership, emotional intelligence, and values in Organizations (Unpublished dissertation), Erasmus-University, Rotterdam.

Elom, S., Okorie, O., Nduka, O., Ekuma, G., \& Otunta, O. (2019). Impact of Emotional Intelligence and Job Satisfaction as Predictors of Burnout among Lecturers of Akanulbiam Federal Polytechnic. The Melting Pot; Journal of the School of General and Basic Studies, 4(1), 102- 109.

Evans, J.D. (1996). Straight forward Statistics for the behavioral sciences. Pacific Grove, CA: Books/ Cole Publishing.

Giao, H. N. K, Vuong, B. N, Huan, D. D., Tushar, H, \& Quan, T. N. (2020). The Effect of Emotional Intelligence on Turnover Intention and the Moderating Role of Perceived Organizational Support: Evidence from the Banking Industry of Vietnam. Sustainability, 12(5), 1857-1882.

Gill, R. (2010). Theory and practice of leadership. London: Sage publications.

Goleman, D. (1995). Emotional Intelligence, New York, NY, England: Bantam Books, Inc.

38 Published by Research \& Innovation Initiative, 3112 Jarvis Ave, Warren, MI 48091, USA 
Goleman, D. (1996). Emotional intelligence: Why it can matter more than IQ. London, Bloomsbury.

Goleman, D. (1998a). What makes a good leader? Harvard Business Review, 76(6), 93-104.

Goleman, D. (1998b). Working with emotional intelligence, Random House, Inc.

Goleman, D. (2000). Leadership that gets results. Harvard Business Review, 78(2), 78-93.

Goleman, D. (2001). An EI-Based Theory of Performance. In C. Cherniss \& D. Goleman (Eds.), The emotionally intelligent workplace: How to select for, measure, and improve emotional intelligence in individuals, groups, and organizations. San Francisco, CA: Jossey-Bass.

Goleman, D., Boyatzis, R., \& McKee, A. (2002).The new leaders: Transforming the art of leadership into the science of results. London: Little, Brown.

Gross, J. J. (1998). The emerging field of emotion regulation: An integrative review. Review of General Psychology, 2, 271-299.

Groves, K. S. (2005). Linking Leader Skills, Follower Attitudes, and Contextual Variables via an Integrated Model of Charismatic Leadership. Journal of Management, 31, 255-277.

Hair, J., Anderson, R., Tatham, R., \& Black, W. (2003). Multivariate Data Analysis with Readings. New Jersey: Prentice-Hall, 18(8), 814-823.

Harms, P., \& Crede, M. (2010). Emotional intelligence and transformational and transactional leadership: A metaanalysis. Journal of Leadership \& Organizational Studies, 17(1), 5-17.

House, R. J., \& Baetz, M. (1979). Leadership: Some empirical generalizations and new research directions. In B. M. Staw (Ed.), Research in organizational behavior, 1, 341-423. Greenwich, CT: JAI Press.

Islam, N. M. (2015). An Introduction to Research Methods (4thed). Dhaka: Mullick \& Brothers.

Leban, W., \& Zulauf, C. (2004). Linking emotional intelligence abilities and transformational leadership styles. Leadership \& Organization Development Journal, 25(7), 554-564.

Levine, K. J., Muenchen, R. A., \& Brooks, A. M. (2010). Measuring transformation and charismatic leadership: Why isn't charisma measured? Communication Monographs, 77(4), 576-591.

Lowe, K. B., Kroeck, K. G., \& Sivasubramaniam, N. (1996). Effectiveness correlates of transformation and transactional leadership: A meta-analytic review of the MLQ. Leadership Quarterly, 7(3), 385-425.

Lubbadeh, T. (2020). Emotional Intelligence and Leadership- The Dark and Bright Sides. Modern Management Review, XXV (27), 39-50.

Malhotra, N. K. (2002). Marketing Research: an applied orientation. New Delhi: Pearson Education Asia.

Mayer, J., Salovey, P., \& Caruso, D. (2000). Models of emotional intelligence. In R. J. Sternberg (Ed.), Handbook of Human Intelligence. New York: Cambridge University Press.

Nandwana, S., \& Joshi, K. (2010). Assessment of emotional intelligence of tribal adolescents of Udaipur: An exploratory study. Studies of Tribes and Tribals, 8(4), 37-40.

Northouse, G. (2019). Leadership Theory and Practice ( $8^{\text {th }}$ Ed.). Thousand Oaks, CA: Sage Publications.

Palmer, B., Walls, M., Burgess, Z., \& Stough, C. (2001). Emotional intelligence and effective leadership. Leadership and Organizational Development Journal, 22(1), 5-10.

Pooja, P., \& Kumar, P. (2016). Demographic Variables and Its Effect on Emotional Intelligence: A Study on Indian Service Sector Employees. Ann Neurosci, 23, 18-24.

Rahim, M. A., Psenicka, C., Oh, S.Y., Polychroniou, P., Dias, J. F., Rahman, M.S., \& Ferdausy, S. (2006). Relationship between emotional intelligence and transformational leadership: A cross-cultural study. In M. A. Rahim (Ed.), Current Topics in Management, 11, 223-236. New Brunswick \& London: Transaction Publishers.

Rahim, M., \& Minors, P. (2003). Effects of emotional intelligence on concern for quality and problem-solving. Managerial Auditing Journal, 18(2), 150-155.

Rahim, M., Psenicka, C., Polychroniou, P., Zhao, J., Yu, C., Chan, K., Susana, K., Alves, M., Lee, C., Rahman, M.S., Ferdausy, S., \&Wyk, R. (2002). A model of emotional intelligence and conflict management strategies: a study in seven countries. International Journal, 10(4), 302-326.

Rahman, M.S. (2018). Relationships among Emotional Intelligence, Leadership Styles, and Job Performance of the Employees in Chittagong Export Processing Zone. Unpublished PhD thesis, University of Chittagong, Bangladesh. 
Rahman, M. S., Uddin, M., \& Rahman, M. (2016). Role of emotional intelligence in managerial effectiveness: An empirical study. Management Science Letters 6, 237-250.

Rahman, M., Ferdausy, S., \& Uddin, M. (2012). Examining the relationships between emotional intelligence and the components of transformational leadership. The ABAC Journal, 32(1), 45-59.

Rahman, M.S., Ferdausy, S., Al-Amin, M., \& Akter, R. (2020). How does Emotional Intelligence Relate to Transformational Leadership, Creativity, and Job Performance? Society $\mathcal{E}$ Sustainability, 2 (1), 1-15.

Salovey, P., \& Mayer, J. (1989, 1990). Emotional intelligence. Imagination, Cognition, and Personality, 9 (3), 185-211.

Saunders, M., Lewis, P., \& Thornhill, A. (2012). Research methods for business students (6th ed.). Harlow: Pearson Education Limited.

Schein, E. H. (1989). Reassessing the "Divine Rights" of managers. Sloan Management Review, 30(2), 63-68.

Shamir, B., House, R. \& Arthur, M. (1993). The Motivational Effects of Charismatic Leadership: A Self-Concept Based Theory. Organization Science, 4(4), 577-94.

Sosik, J. J., \& Megerian, L.E. (1999). Understanding leader emotional intelligence and performance: The role of selfother agreement on transformational leadership perceptions. Group \& Organization Management, 24(3), 367390.

Tareq, M. A., Khazaei, H., \& Khazaei, A. (2017). Relationship between Emotional Intelligence and Charismatic Leadership among Postgraduates in Malaysia: PLS-SEM Analysis. Innovation and Management, 265-271.

Wang, E., Chou, H., Jiang, J. (2005) The Impacts of charismatic leadership style on team cohesiveness and overall performance during ERP Implementation. International Journal of Project Management, 23, 173-180.

Weinberger, L. (2003). An Examination of the Relationship between Emotional Intelligence, Leadership Style, and Perceived Leadership Effectiveness (Unpublished Ph.D. Thesis), St. Paul, MN: Human Resource Development Research Center.

Zikmund, W. G. (2009). Business Research Methods ( $8^{\text {th }}$ ed.). The Dryden Press: Fort Worth.

(C) 2021 by the authors. Licensee Research \& Innovation Initiative, Michigan, USA. This article is an open-access article distributed under the terms and conditions of the Creative Commons Attribution (CC BY) license (http://creativecommons.org/licenses/by/4.0/). 